\title{
Rethinking Curriculum for Competency-Based on Contests Hampering Student Support in Open Distance Learning Space: South African Perspectives
}

\author{
Rudzani Israel Lumadi \\ Department of Educational Leadership and Management \\ University of South Africa, Gauteng Province, Pretoria,South Africa
}

\begin{abstract}
The central aim of this article is to determine the contest facing student support in open distance learning context. All of those activities and services in education have developed to assist students to achieve their academic achievements and to improve relevant knowledge in order to achieve their goals in their lives. This article determine the access contest hampering student support in open distance learning (ODL). There is a growing primary recognition concern of the lack of student support services in the making distance education more responsive to the students. Student support activities including teaching and tutoring activities guide students to achieve their studies. The main purpose of the article is to develop an understanding of the contest facing student support as a result colonial practices that still practiced in open distance learning (ODL) system of democratic era in South Africa. Qualitative method was employed to collect data to answer the question about this article asks what are the contest hampering student support in open distance learning (ODL). This study employed an interpretive design to conduct the research.
\end{abstract}

A sample of 210 students was used for the study, obtaining a random sampling of 100 students out of 210-registered student in the KwaZulu-Natal Province. The study findings revealed that there are student support gap and negative impact on students' academic achievement in open distance learning context. I argue in this study that student support could be the stimulus for the renewal of the field of educational management studies in South Africa. I clarify in this 
study what is the meaning of the concept student support in open distance learning space. It is recommended that Crocodile University should train its academic, administration staff and

tutors to bridge the gap of student support activities they offer. I hope that this study will contribute to effective delivery of student support services for the students at open and distance learning institutions.

Key words: Contest, student support, open distance learning, colonial practice, socioeconomic imbalances, academic achievement, and student gap, student dropout

\section{INTRODUCTION}

The central aim of student support in open distance learning is to assist students to learn successfully, and recognise that in teaching and learning systems characterised by geographical distance. This article reports on an increasing number of recognition commentaries concern about lack of student support that affect students' performance and achievement. Open and distance learning is an important factor of higher education which plays an important role in the growth and promotion of higher education contributing to educational development and equality. At this point, Tait (1995) contends that students support is an element of open distance learning which are up of the following: tutoring, telephone, information and communication technologies as well as other service activities.

Student support is a universal term that is applied to the variety of services that are established by institutions in order to assist their students to achieve their learning aims; to improve the knowledge to be successful and complete their academic studies. There are several ways to support students in open distance learning in order to improve their academic achievements including tutorials, guidance, WhatsApp, sms and information and communication technologies (ICT). These student service activities have as key conceptual components the notion of supporting the individual student while in contrast the mass produced elements are identical for all students. Lack of student support in open distance spaces is associated with poor academic performances. In the same vain, Fraser and Van Staden (1996) state that levels of dropout and withdrawal from distance education programmes at the tertiary level tend to be 
higher than for comparable residential courses and are a matter of concern to providing institutions. Previous research has given some factors that can contribute to failure of students in open distance learning (Brindley and Jean-Louis, 1990). For example, inadequate student support is an identified major weakness in the Crocodile University.

Student support activities include lecturing, tutoring counselling and advising. This article determines to what extent the student support impacts on student's learning as part of teaching at the open distance learning.

This article determines the contest that students face in accessing the student support services the university offers.

Establishing the importance of student support in open distance learning (ODL) system for the society in the South African economy, lack of the student support in open distance learning has become a central issue for the students. The issue of lack of students support has received considerable critical attention. My main reason for choosing the contest hampering student support in open distance learning (ODL) system is personal interest is to bridge the student support gap. The central question in this article asks what are the contest which hampers student support in open distance learning (ODL) system. Previous studies have reported that some factors that can contribute to lack of students support in open distance learning (Brindley and Jean-Louis, 1990).

Factors found to be influencing the contest facing students support have been explored in several studies. Data was collected by means of document analysis /literature and focus group interview to examine the contest of student support services offered by the Crocodile University. A sample of 210 students was used for the study, obtaining a random sampling of 100 students out of 210-registered student in the KwaZulu-Natal Province. Random selected samples have the advantage that they yield research data that can be generalised to a larger population (Gall, Borg and Gall, 1996).

This article provided an important opportunity to advance the understanding of attempting on strengthening the student support by paying a particular attention on the strategies to create the student support culture would enable students to reflect on what they have learnt so that they may reflect on the ideas and take advantage of their learning development (Haggis, 2004). Student support should be a fundamental part of ensuring quality teaching and learning. The practices, processes, trends, effects, attitudes and beliefs used in student support should ensure 
that students' academic achievement is of a high standard. In the same vein, effective student support practices within an open distance-learning (ODL) system may contribute to successful student academic achievement. The lack of student support practices within an open distancelearning (ODL) system may result in the system of not addressing the importance of improving quality teaching and learning. According to Fry, Ketteridge and Marshall (2009), increase of student numbers in open distance learning (ODL) system, more emphasis on student support practices opportunities afforded by information and communication technology (ICT) demand that lecturers and tutors should be equipped with relevant skills to deal with the rapid expansion of the use of technology in open distance learning institutions. Students in open distance learning institutions should be provided with an effective student support in order to achieve better academic results. However, it may be argued that student support practices contribute to successful student academic achievement in open distance learning institutions. Kamau (2012) claims that ODL has transformed educational landscape shift from its independence on print media to the application of information and communication technology (ICT) to deliver module content and to facilitate support for distance students.

ODL institutions have a number of student support services in place to support its students but it appears that most of the students particularly from the rural areas find it a bit of hampering to access the services satisfactorily. It is difficult for the unemployment and poverty stricken community to study through the traditional contact system to realise their goals. Crocodile University uses the following tools; information and communication technologies (ICT), telephones, video-conferencing, workshops and face-to- face tutorials to support its students. This article argues that the Crocodile University should identify the contest that face students support activities.

This paper argues that there is a need for Crocodile University to find out what are the contest, which hampers student support in open distance learning (ODL) system.

The main aim of this article is to determine the contest facing student support in open distance learning context.

\section{THEORETICAL FRAMEWORK}

According to Moore (1993) student support in open distance learning institution is a major challenge that is almost concerned by students, parents, politicians and public. Student support 
in open distance learning institutions is therefore a phenomenon that has multiple causes that needs to be researched.

Moore's theory of transactional distance is the psychological and communications space that separates the lecturer and the student that includes the support services they need.

The theoretical framework underpinning this article is Moore's theory of transactional distance that refers to the distance that exists in all educational relationships. In the same vein, Tait (2003) maintain that distance learning (ODL) system is determined by the amount of dialogue that occurs between the student and the lecturer, and the amount of structure that exists in the design of the course. Moore's theory of transaction distance relevant for this article because an ODL institution appears to exhibit some features of transactional distance because of the contest students' face in accessing its support services.

Theories, strategies and approaches need to be developed that will address appropriate student contest and provide student support of open distance learning institutions. Theories must be developed that speak to the needs and concerns of the students (Garrison and Anderson, 1999). The Moore's theory of transaction distance assumed to be a possible tool of exhibit transactional open distance based on the contest student face in accessing its support activities.

\section{RESEARCH METHODOLOGY AND DESIGN}

Qualitative research approach was employed to collect data to answer the question about this article asks what are the contest hampering student support in open distance learning. The student support have been the most effective services which, should be improved and include students' subjective experiences. Qualitative design is a method that attempts to understand and interpret what exists at present in the form of practices, processes, trends, effects, attitudes and beliefs, as they perceived and experienced by the actors (Manwa, 2014). According to Patton (2001), qualitative research uses a naturalistic phenomenological approach that seeks to understand phenomena in context-specific setting of the real world settings the researcher does not attempt to manipulate the phenomenon of interest.

Research question

The main research question is: 
- What are the contest of the students face in accessing the student support activities provided by Crocodile University?

Sub-question

- What gaps prevent the students from accessing the student support activities offered by Crocodile University?

This article investigates the contest that students face in accessing the student support services the university offers.

I used document analysis /literature study and focus group interview to examine the contest of student support services offered by the Crocodile University. The population for this study was made up of all postgraduate Certificate in Education (PGCE) registered students specifically from the KwaZulu-Natal Province of South Africa in 2018. A random sample of subjects was drawn from the define population.

A sample of 210 students was used for the study, obtaining a random sampling of 100 students out of 210-registered student in the KwaZulu-Natal Province. Random selected samples have the advantage that they yield research data that can be generalised to a larger population (Gall, Borg and Gall, 1996). The postgraduate Certificate in Education (PGCE) is a program of oneyear qualification to train graduates who wish to become school teachers. The qualification provides professional registration with the South African Council for Educators (SACE) for graduates with degrees other than the B.Ed. Admission to the PGCE is based on what subjects have been studied for the undergraduate degree, according to the guidelines issued by the Department of Higher Education and Training. Teacher training is in accordance with appropriate prior courses in the subjects to be taught. Data was collected from PGCE students across Kwazulu-Natal province. The details of the participants obtained from the information and communication technology (ICT) department at Crocodile University.

This researcher employed interprivist paradigm for the study using a focus group to understand the views of the students on the contest they face in accessing the student support activities offered by the university. Similarly to Cohen et al, (2007:19), argue that the role of the scientist in the interprivist paradigm is to understand, explains and demystify social reality through the eyes of different participants. I used the interprivist paradigm to seek to understand rather than 
explain. The focus group interview was designed to help the researcher to obtain relevant information from the participants.

\section{Data Collection and analysis}

Qualitative method was employed to collect data to answer the question about this article asks what are the contest hampering student support in open distance learning (ODL). Hsieh \& Shannon, 2005 assert that this is a research is method for the subjective interpretation of the content of the text data through the systematic classification process of coding and identifying themes. The aim of using the interpretive paradigm is to explain the subjective reasons and meanings that lie behind the student's interaction with various student support services. Mertens (1998), the assumptions guiding the interpretive paradigm are that people active in the research process socially construct knowledge, and that researchers should attempt to understand the complex world of lived experience from the point of view of those who live it. The data was collected through focus group interview. The focus group was conducted at the Crocodile University to access students thoughts on how the learner support services met contest they faced in accessing the services provided by the university.

\section{FINDINGS AND DISCUSSION}

Based on the affluence of information gathered from participants, the important data are presented to answer the study's research question. Based on the findings developed and presented the themes that describe the relevant information to answer the study's research question.

Distribution of study materials

Study materials in self-learning materials are to be distributed in accordance with the university policy. It is desirable to deliver the study materials by hand to the students at the time of student admission.

While distance education practice has relied heavily on print, only recently have distance education theorists begun to recognize the unique characteristics of text-based communication 
and realize that such communication may affect the facilitation of learning outcomes in different ways (Garrison, et al., 2000; Peters, 2000).

\section{Administrative and academic support}

The availability of administrative and academic staff are the most important to the students' success in open distance (ODL) institution. The students face contest of unavailability of the administrative and academic support staff services that enables the effective learning which satisfy the academic students' needs. Student support should consider the administrative framework that is required to support the management and dissemination of information to and from the students.

One of the students said that:

"Some of the staff members are rude, impatient with the students, and difficult to respond to the students' emails and telephone calls." Sometimes you wanted to give up and stuff but you carried on with your studies. You end up consoling yourself by saying there is a way that you will get through it.

Furthermore, the researcher believes that if the administrative and academic support is to achieve its mission of making quality higher education accessible to students, assessment strategies need to be put in place to find out whether this mission has been achieved. In an institution where administrative information management are ineffective not being timely, or being obstructive through admitting no exceptions students will be pushed out. The quality and nature of the development and management of student support services provided by the teaching staff and managers depend on a number of factors, professional competence, values and policy of the open and distance learning institution.

\section{Drop out reduction}

Student dropout rates have become an unescapable difficulty in open and distance learning institution. There are several reasons for students dropping out from the open distance learning usually involved multiple factors has rather broad implications. The intervention when students 
have not contributed work on time can make a timely and effective contribution to the reduction of dropout. The contact through information and communication technology (ICT) between institution and students significantly influenced student commitment and persistence.

\section{Another student complained that:}

"High dropout and low graduation rates in distance education institution is an elephant in the room in distance education." The students from poor socio-economic backgrounds who are trying to access higher education to better their living conditions. Most of these students live in rural areas where there is poor internet connection. The access to student support services is very difficult to obtain and consequently leads to high dropout.

\section{Transactional framework}

Moore's theory of transactional distance is the psychological and communications space that separates the lecturer and the student that includes the support services they need, such as the tutoring and mediated programs that enable them to perform and realise their academic goals (Moore, 1993:23-24). Basson and Nonyongo (1997) assert that transactional distance, as a concept, derives from the belief that distance education provision is an interactive participatory experience for both the providing institution and for its students.

Transactional framework implies that two parties (institution through academic staff and students) are involved in an action of communication and contract form. According to Basson and Nonyongo (1997), the provision of distance education should follow a "student-oriented" or "responsive" approach.

\section{One respondent remarked:}

Transactional framework puts the highlighting on the institution through academic staff and students involved and the contracts between them, rather than on the structures stressed by the system approach.

\section{RECOMMENDATION}

There is a tendency to drop out by the students in open distance education and Keegan (2001) emphasise that this tendency can be attended to by planning quality course materials by providing effective and efficient student support services for the avoidance of avoidable 
dropout. The tutor should give teaching feedback and the mark for work completed during the course, thus having a pivotal role in supporting student learning and progress. All students should be given the opportunity to take part in face-to-face tutorials, and even in computermediated tutorials, managed by their own tutor.

The students should have realistic expectations for student-tutor engagement and responsiveness. It is improbable that a tutor could have a personal relationship with every student in an open distance learning when he or she often teach multiple course sections with as many students (Hannum \& McCombs, 2008).

\section{CONCLUSION}

In the article I have attempted to outline the importance of student support is an empowering and strengthening methods, of paying a particular attention on the strategies to create the student support culture that would enable students to reflect on what they have learnt so that they may reflect on the ideas and take advantage of their learning development. The main aim of this article is to determine the contest facing student support in open distance learning (ODL) system. The hampering student support is to provide an understanding of the opportunities and limitations of facilitating teaching and learning at an open distance learning with strategies and Information and communication Technologies. The student support will demand theories that reflect a collaborative approach to open distance learning and have at their core an adaptive teaching and learning transaction.

The student support is characterized by a compliance of design before and during the teaching and learning process made possible by affordable and interactive information and communications technology. The Crocodile University provides a number of student support services to its students but it appears that students are unable to access their services properly. In order to implement the student support successfully, the regional centres needs to allocate more institutional resources to aspects of career counselling and academic planning.

\section{REFERENCES}

Basson, R. and Nonyongo, E. (1997). Interpreting the student perspective on dusspro tutorial support and its implications for a distance education provider. SAJHE/SATHO, 11(2): 97110. 
Brindley, J. (1987). Attrition and completion in distance education: The student's perspective. Unpublished M.A. thesis. Vancouver: University of British Columbia.

Cohen, L. Manion, L. and Morrison, K. (2007). Research methods in education 6th edition. London: Routledge.

Fraser, W.J. and van Staden, C.J.S. (1996). Students' opinions on factors influencing dropout rates and performance at distance education institutions. South African Journal of Education, 16(4): 216-223.

Fry, H. Ketteridge, S. Marshall, S. (2009). A Handbook for Teaching and Learning in Higher Education Enhancing Academic Practice ( $3^{\text {rd }}$ Edition). London: Taylor and Francis Group. Gall, M.D., Borg, W.R. and Gall, J.P. (1996). Educational Research: An Introduction, 6th edition. New York: Longman Publishers.

Garrison, D. R., Anderson, T., and Archer, W. (2000). Critical Inquiry in a Text-based Environment: Computer conferencing in higher education. The Internet and Higher Education, 2(2-3), 1 - 19.

Hannum, W. H., \& McCombs, B. L. (2008). Enhancing distance learning for today's youth with learner-centered principles. Educational Technology, 48, 11-21. Retrieved from http://asianvu.com/bookstoread/etp/

Hsieh, H.F. \& Shannon, S.E. 2005. Three approaches to qualitative content analysis. Qualitative Health Research, 15(9):1277-1288.

Kamau, J. W. (2012). The effectiveness of learner support services to distance learners in a primary education diploma: A case study in Botswana. Unpublished doctoral thesis, University of Pretoria: Pretoria.

https://repository.up.ac.za/bitstream/handle/2263/24076/00front.pdf?sequence=1

Manwa, L. 2014. Determinants of Academic Performance of female students at a University in Masvingo Province, Zimbabwe. Pretoria: University of South Africa.

Mertens, D.M. (1998). Research Methods in Education and Psychology: Integrating Diversity with Quantitative and Qualitative Approaches. London: Sage Publications.

Moore, M.G. (1993). Theory of transactional distance. In Keegan, D. (Ed.), Theoretical principles of distance education. London: Routledge. 
International Conference on

New Trends in Teaching and Education

5-7 September, 2019

Barcelona, Spain

Tait, A. (2003). Reflections on student support in open and distance learning. International Review of Research in Open and Distributed Learning, 4(1). http://www.irrodl.org/index.php/irrodl/article/view/134/214 